\title{
MICROBIOLOGICAL STUDY OF DIABETIC FOOT ULCERS IN AN INDIAN TERTIARY CARE HOSPITAL
}

F. Shahnooshi Javad ${ }^{*}{ }^{1}$, Masoud Reazvanian ${ }^{2}$, Sangeet Kumar ${ }^{3}$ and Hossein Norouzi ${ }^{4}$

Doctor of Pharmacy 1, Department of Pharmacy Practice, Krupandhi College of Pharmacy, Chikkabellandur Village, Varthur Hobli, Bangalore - 560035, Karnataka, India.

Centre for Drug Delivery Research ${ }^{2}$, Faculty of Pharmacy, Kebangsaan Malaysia University, Jalan Raja Muda Abdul Aziz, 50300, Kuala Lumpur, Malaysia.

Department of Pharmacy ${ }^{3}$, Sinhgad College of Pharmacy, Vadgaon, Pune - 411041, Maharashtra, India. Department of Microbiology ${ }^{4}$, Bharati Vidyapeeth University, Pune - 411030, Maharashtra, India.

\begin{abstract}
Diabetes mellitus is one of the most critical health conditions around the world, not only in terms of the number of affected people, disability, and premature mortality but also in regards to the health care costs involved in controlling and treating its complications. Among the most constant ailments, the diabetic patient suffers is the diabetic foot, defined as any infection, ulceration, and necrosis of deep tissues associated with neurological abnormalities and various degrees of peripheral vascular disease of the lower limbs. This study determines the microbiological profile and antibiotic susceptibility patterns of organisms isolated from diabetic foot ulcers. A record based study was conducted among 169 diabetic foot ulcer patients admitted in the hospital; Details regarding the Culture and antibiotic susceptibility of specimens (pus samples from foot ulcers) from these 104 patients were collected. Commonest microorganisms isolated in this study were Pseudomonas, Staphylococcus, Klebsiella, Proteus, and E. coli. Gram-positive organisms were highly sensitive to Vancomycin, Linezolide, and gram-negative were sensitive to Amikacin and Meropenam.
\end{abstract}

Keywords: Microbiological profile, Gram positive, Gram negative, Antibiotic susceptibility

\section{Correspondence to Author:}

F. Shahnooshi Javad

Doctor of Pharmacy, Department of Pharmacy Practice, Krupandhi College of Pharmacy, Chikkabellandur Village, Varthur Hobli, Bangalore - 560035, Karnataka, India.

E-mail: Javad.sh1989@gmail.com

INTRODUCTION: Diabetes mellitus (DM) is a common, chronic, debilitating, and sometimes fatal endocrine disease with constantly growing global prevalence. In 2011, about 366 million people suffered from DM, and in 2030, the number would rise to 552 million ${ }^{1}$.

\begin{tabular}{|c|c|}
\hline QUICK RESPONSE CODE & DOI: \\
\hline Dol link: http://dx.doi.org/10.13040/IJPSR.0975-8232.IJLSR.1(2).65-70 \\
\hline www.ijlsr.com
\end{tabular}

DM encompasses Type 1 DM, which can be associated with autoimmune damage of the pancreatic $\beta$ cells, Type $2 \mathrm{DM}$, resulting from insulin resistance and disorder of insulin secretion and gestational DM, which can progress to Type 2 DM in the years afterward ${ }^{2}$.

Type 2 DM encompasses most (usually 90-95\%) of all diabetic patients. It is worrying that $26.9 \%$ of the people aged $>65$ years and $11.3 \%$ of those aged $>20$ years had diagnosed or non-diagnosed DM in the USA in 2011. ${ }^{3}$ Worldwide, diabetic foot lesions are a major medical, social, and economic problem 
and are the leading cause of hospitalization for patients with diabetes. Infectious agents are associated with amputation of the infected foot if not treated promptly. Proper management of these infections requires appropriate antibiotic selection based on culture and antimicrobial susceptibility results; however, initial management comprises empirical antimicrobial therapy, which is often based on susceptibility data extrapolated from studies performed on general clinical isolates ${ }^{4}$. Several studies found methicillin-resistant Staphylococcus aureus (MRSA) in as many as 15$30 \%$ of diabetic wounds $5,6,7$.

Infection with multidrug-resistant organisms (MDROs) may increase the duration of hospital stay and cost of management and may cause additional morbidity and mortality. Among diabetic individuals, foot infections are the most frequent complication in the patient, accounting for $20 \%$ of diabetic related hospital admissions ${ }^{8}$. Diabetic Foot Infection [DFI] or Diabetic Foot Ulcer [DFU] is defined as the infection caused by the introduction of an infectious agent into the otherwise sterile soft tissue of the foot through minor skin break. Infectious agents are usually associated with the worst outcome, which might lead to amputation of the infected foot unless prompt treatment strategies ensue. Though many studies have reported on the bacteriology of diabetic foot infections (DFIs) over the past 25 years, the results have varied and have often been contradictory 9,10 .

So, conducting surveillance study at equal intervals is a must to assess \& update the condition prevailing. Drug resistance is a global problem affecting both developed and undeveloped countries. Antimicrobial resistance is a natural consequence of antimicrobial use, which kills the sensitive organisms leaving the resistant ones to survive and multiply (selection of resistance). Overuse and misuse of antimicrobials do not help patients; they merely add to the problem of resistance and waste resources. Antimicrobial resistance is on the increase - threatening our ability to treat some of the infectious diseases that cause most deaths. Infectious diseases still account for $45 \%$ of deaths in low-income countries and almost one in two premature deaths worldwide ${ }^{11}$. Today antibiotics remain the first line therapy for conquering bacterial infections. However, their indiscriminate use is no longer viewed as benign. Treatment with these drugs is acknowledged to be a two-edged sword. As antimicrobial agents have been misused or overused, bacteria have fought back with a selection process by which certain strains are no longer susceptible to one or more agents. Each new use of these drugs, in fact, contributes to the evolution of resistant microorganisms 12, 13. Empirical antibiotic recommendations $14,15,16$ by type of infection, are given in Table 1.

METHODOLOGY: A record based study was conducted among 169 diabetic foot ulcer patients admitted to the hospital in Pune. Patients with diabetic foot infections were identified whose microbiology request forms sent along with the clinical specimens to the Department of Microbiology. Prescription data were collected from the medical records that contain all the prescriptions for each patient, providing information about the demographic details, drugs prescribed empirically, culture and sensitivity reports of the patients were collected for analysis. Culture and sensitivity reports of patients were screened to determine the prevalence of sensitivity and resistance pattern of a particular organism to different antibiotics were determined. The data obtained were tabulated, and results are interpreted using cross tabulation for SPSS software has been used. The data collected from all the participants were recorded in a spreadsheet format and analyzed using the software JMP $8 \circledR$ TM academic license from SAS ${ }^{\circledR}$ Inc, and cross-tabulation for SPSS software has been used for any statistical significance. Significance was reported by $95 \%$ Confidence Interval.

RESULTS: Males were predominant $(76.33 \%)$ in the study subjects. The majority of subjects had type 2diabetes $(96.44 \%)$. Most of the participants were in 40 to 60 years old range, Fig. 1. $36.09 \%$ had the condition for $>10$ years. $81.6 \%$ of cases were using insulin treatment at the time of admission. $37 \%$ of participants did not have any complications, $23.07 \%$ had Gangrene, and only 2\% had Septicaemia. Osteomyelitis was present in 50 (62.5\%) subjects Table 1. A total of 186 isolates were detected from the 169 ulcer specimens, averaging 1.1 species per patient. 
TABLE 1: SUGGESTED ANTIBIOTIC REGIMENS FOR TREATMENT OF DIABETIC FOOT INFECTIONS

\begin{tabular}{|c|c|c|c|}
\hline $\begin{array}{c}\text { Severity of } \\
\text { infection }\end{array}$ & $\begin{array}{c}\text { Route of } \\
\text { administration }\end{array}$ & $\begin{array}{l}\text { Recommended agents } \\
\text { (choose one or more) }\end{array}$ & $\begin{array}{c}\text { Alternative } \\
\text { agents }\end{array}$ \\
\hline Mild/moderate & Oral & $\begin{array}{c}\text { Cephalexin (500 mg q.i.d.) OR Dicloxacillin } \\
\text { ( } 250 \mathrm{mg} \text { q.i.d.) OR Clindamycin ( } 300 \mathrm{mg} \\
\text { t.i.d.) OR Amoxicillin/ clavulanate ( } 875 / 125 \\
\text { mg b.i.d.) }\end{array}$ & $\begin{array}{c}\text { Levofloxacin (750 mg q.d.) } \pm \\
\text { Clindamycin (300 mg t.i.d.) } \\
\text { OR Trimethoprim-sulfamethoxazole ( } 2 \\
\text { double-strength b.i.d.) }\end{array}$ \\
\hline Moderate/severe & $\begin{array}{l}\text { Intravenous until stable, } \\
\text { then transition to an oral } \\
\text { equivalent (or tailor based } \\
\text { on culture results) }\end{array}$ & $\begin{array}{l}\text { Ampicillin/sulbactam (3.0 gm q.i.d.) } \\
\text { OR Clindamycin (450 mg q.i.d.) + } \\
\text { ciprofloxacin (750 mg b.i.d.) }\end{array}$ & $\begin{array}{l}\text { Piperacillin/tazobactam (3.3 gm q.i.d.) } \\
\text { OR Clindamycin ( } 600 \mathrm{mg} \text { q.i.d. })+ \\
\text { ceftazidime ( } 2 \text { gm t.i.d.) OR } \\
\text { Ertapenem (1 gm q.d.) }\end{array}$ \\
\hline Life-threatening & Prolonged intravenous & $\begin{array}{c}\text { Imipenem/cilastin (500 mg q.i.d.) } \\
\text { OR Clindamycin (900 mg q.i.d.) }+ \\
\text { tobramycin (5.1 mg/kg/d) + ampicillin (50 } \\
\mathrm{mg} / \mathrm{kg} \text { q.i.d. })\end{array}$ & $\begin{array}{l}\text { Vancomycin }(15 \mathrm{mg} / \mathrm{kg} \text { b.i.d. })+ \\
\text { aztreonam }(2.0 \mathrm{gm} \text { t.i.d. })+ \\
\text { metronidazole }(7.5 \mathrm{mg} / \mathrm{kg} \text { q.i.d. })\end{array}$ \\
\hline
\end{tabular}

TABLE 2: GENERAL CHARACTERISTICS OF STUDY SUBJECTS

\begin{tabular}{cccc}
\hline \multicolumn{2}{c}{ Characteristics } & Frequency & Percentage \\
\hline \multirow{2}{*}{ Gender } & Male & 129 & 76.33 \\
Type of Diabetes mellitus & Female & 40 & 23.77 \\
& Type I & 6 & 3.55 \\
Duration & Type II & 162 & 96.44 \\
& Newly detected & 8 & 4.73 \\
& 1 year & 12 & 7.100 \\
& $1-5$ years & 29 & 17.15 \\
& $6-10$ years & 59 & 34.91 \\
Complications other than foot & Peripheral occlusive vascular & 61 & 36.09 \\
ulcer among Type II Diabetic & disease & 16 & 9.46 \\
patients & Septicaemia & 4 & 2.36 \\
& Neuropathy & 24 & 14.20 \\
& Retinopathy & 3 & 1.77 \\
& Osteomyelitis & 36 & 21.3 \\
Type of treatment at the time & Gangrene & 39 & 23.07 \\
of admission & None & 63 & 37.27 \\
& Insulin & 138 & 81.65 \\
& Oral hypoglycaemic drugs & 31 & 18.34 \\
\hline
\end{tabular}

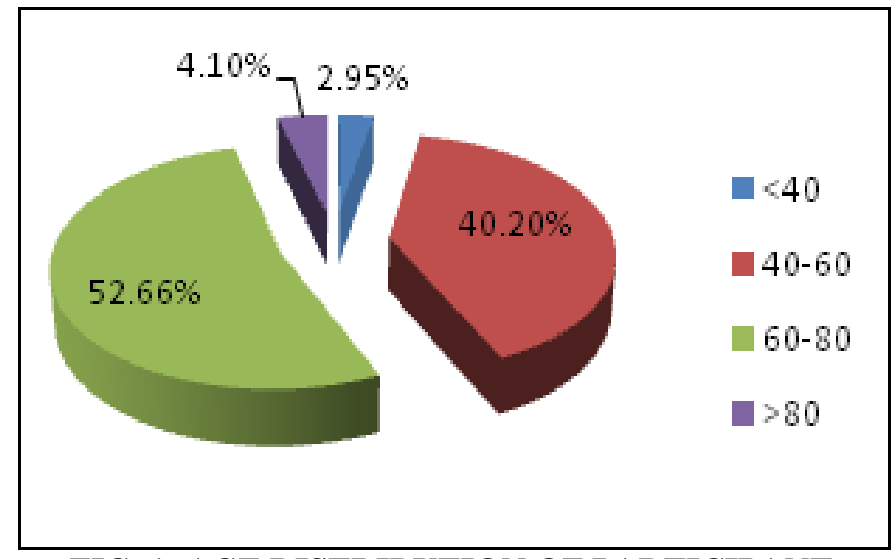

FIG. 1: AGE DISTRIBUTION OF PARTICIPANT

Gram-positive organisms isolated were 71 out of a total of 186 organisms (38\%), and gram-negative organism isolated was 115 out of 186 organisms (61\%). The profile of the gram-positive organisms isolated is detailed in Fig 2. Of the total $31.87 \%$ gram-positive isolated, Staphylococcus is mostly detected (19.89\%) while coagulase-negative
Staphylococcus were in less number as compare to another gram-positive organism (3.22\%). Among gram-negative organism Fig. 3 the most common isolates were Proteus sp. (18.27\%), Pseudomonas (13.97\%), E. coli (13.44\%) The other gramnegative isolates found to be associated were Klebsiella and Citrobacter.The results of susceptibility studies to Gram-positive organism are summarized in Fig 4. Most of the Grampositive were found to be highly resistant to penicillin (92\%), gentamicin (77\%), and erythromycin (88\%). But they showed good sensitivity to a cephalosporin (69\%), amikacin (59\%) and rifampicin (67\%). They have not yet shown resistance to vancomycin or linezolid. The results of susceptibility studies to Gram-negative organism are summarized in Fig 5. In the case of gram-negative isolated, we observed good sensitivity of these organisms to amikacin (63\%) and meropenem (59\%). 


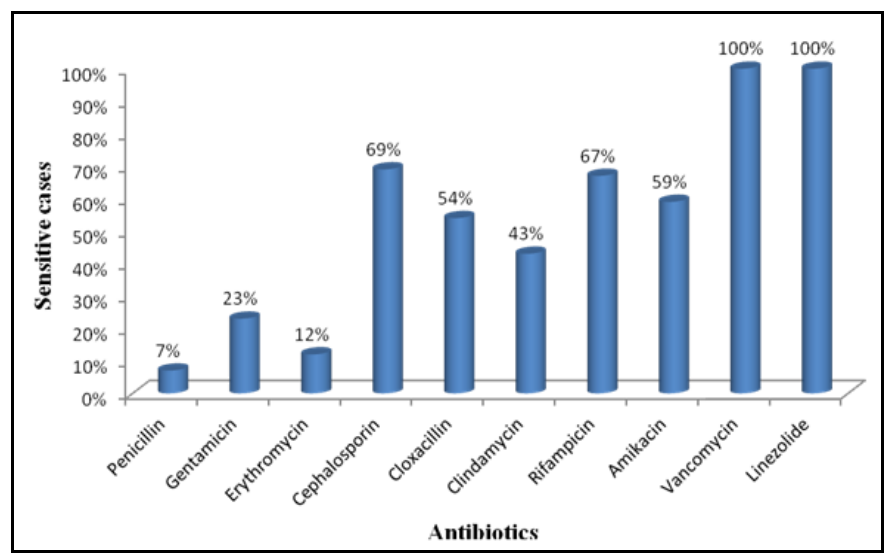

FIG. 2: COMPARATIVE FREQUENCY OF THE ORGANISMS ISOLATED (GRAM POSITIVE). No of specimens: 169 . Total no. of the organism isolated: 186 . Total no. of gram-positive isolated: 71/186 (38.17\%).

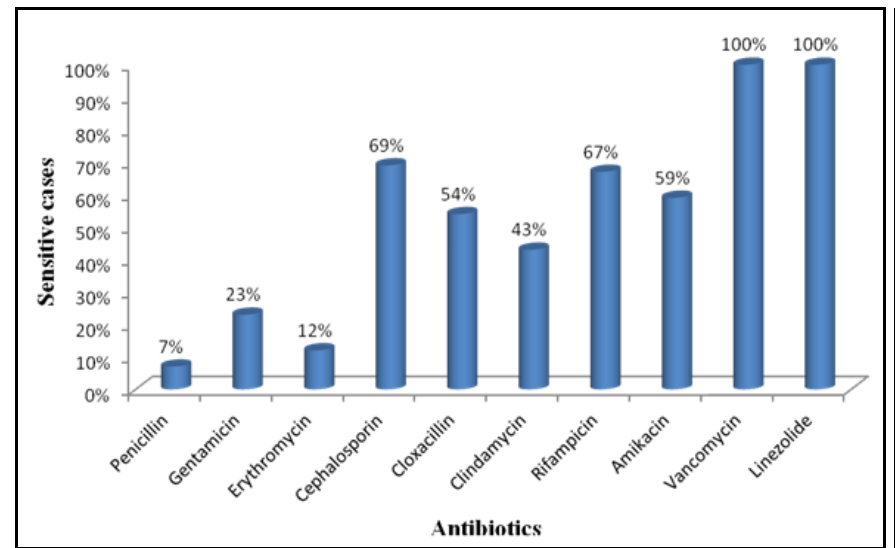

FIG. 4: ANTIBIOTIC SUSCEPTIBILITY OF GRAMPOSITIVE ORGANISM

Thirty-four percent of organism showed sensitivity to Piperacillin and Tazobactam combination. On the other hand, no sensitivity detected in treatment with Ampicillin. Most of the gram-negative were found to be highly resistant to Cephalosporine 1 (3\%) and Cephalosporine 111 (2\%) followed by Gentamicin and Aztreonam (7\% for both).

DISCUSSION: Our study revealed that no. Males attending the foot infection were more than the no. of females and the main age group involved was patients above the age of 60 years. The majority of the study population had Type 2 diabetes mellitus, and most of the participants had a history of diabetes for more than 6 years. Our results showed that the 186 specimens yielded about 38\% Gram positive sp. and $61 \%$ gram negative spp. The frequency of gram-negative organism was higher to the frequency of gram-positive; this result was by some study 18, 19. Foot infections in diabetes are rarely due to a single organism 20, 21. Aerobic bacteria (Staphylococcus spp., Streptococcus spp.,

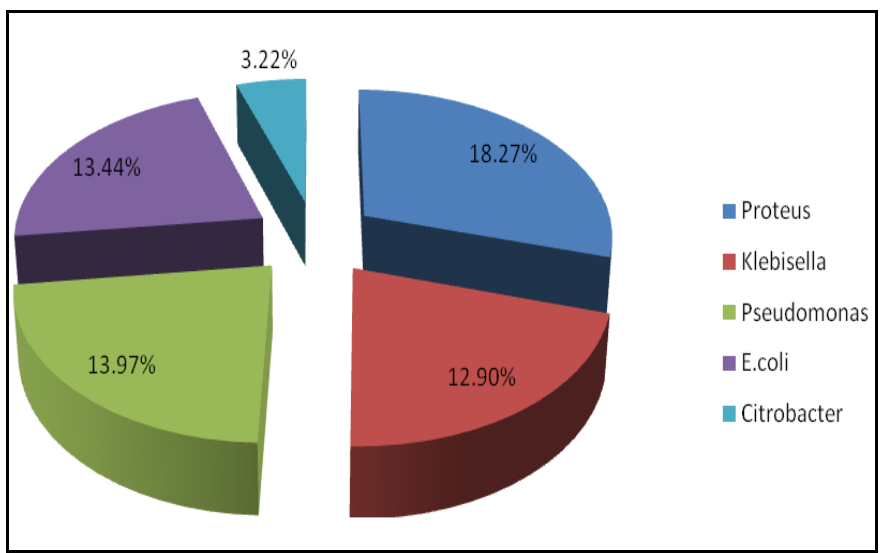

FIG. 3: COMPARATIVE FREQUENCY OF THE ORGANISMS ISOLATED (GRAM NEGATIVE). No. of specimens: 169 . Total no. of the organism isolated: 186. Total no. of gram-positive isolated: 115/186 (61.82\%).

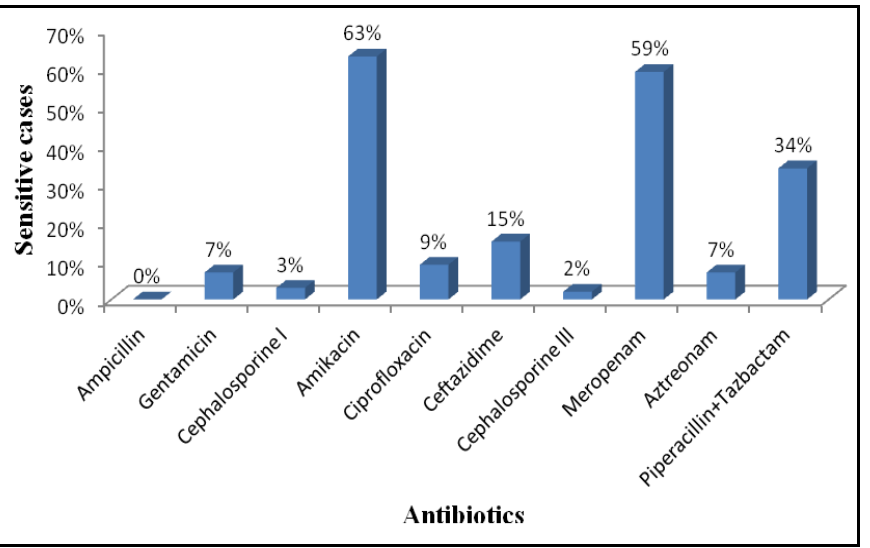

FIG. 5: ANTIBIOTIC SUSCEPTIBILITY OF GRAMNEGATIVE ORGANISM

\& Enterobacteraciae), anaerobic flora (Bacteroides sp., Clostridium sp., and Peptostreptococci sp.), and fungi are the organisms that are isolated mot often. $^{22}$ In this study a total of 186 isolates were detected from the 169 ulcer specimensns, averaging 1.1 species per patient. Only $9.8 \%$ of the subjects had infections due to more than one organism. In this study, $61 \%$ of organisms isolated from diabetic foot ulcers were gram-negative organisms, and $38 \%$ of organisms were gram-positive organisms.

Gram-positive aerobic bacteria were found to be the predominant organisms causing diabetic foot infections in many studies 23,24 . But the more recent studies report gram-negative aerobes to be the commonest organisms in diabetic foot ulcers ${ }^{25}$, 26. The predominant gram-positive Cocci isolated were Staphylococcus aureus, this was in accordance to study conducted in Indian tertiary care hospital and a US hospital ${ }^{27}$. The isolation rate of Enterococci spp. was $11.29 \%$, which was lesser than the isolation rate reported by a study 
conducted in US ${ }^{28}$. In the case of the gramnegative organism, Proteus was the organism isolated in $18 \%$ samples. Pseudomonas and E.coli were second and third commonest. They are followed by Klebsiella and Citrobacter. Staphylococcus aureus, Pseudomonas aeruginosa, Proteus mirabilis, and Bacteroides fragilis are the most common causes of diabetic foot infections ${ }^{29}$, 30,31. Non-anaerobes were observed in this study.

Most of the study elucidates that gram-positive organism exhibited resistance to Penicillin and Erythromycin ${ }^{32,33}$ this result was completely the same to our results where our strains isolated exhibited resistance pattern to the mentioned antibiotics. A study from Nigeria also reports that the resistance percentage of the Gram-positive isolates from diabetic foot ulcers was Gentamicin $89 \%$, Clindamycin $88 \%$. This was higher when compared to the results of our study 34,35 . Most Gram-negative is highly resistant to antibiotics such as ampicillin, Gentamicin, Cephalosporins, Ciprofloxacin, and Aztreonam. They show good sensitivity to Amikacin, Meropenem, and Piperacillin - Tazobactam. Likewise, most of the studies show high resistant of a gram-negative organism to Ampicillin, Cephalosporine, Aztreonam ${ }^{31,10}$.

CONCLUSION: Commonest microorganisms isolated in this study were Pseudomonas, Staphylococcus, Klebsiella, Proteus, and E. coli. Gram-positive organisms were highly sensitive to Vancomycin, Linezolid, and highly resistant to Penicillin. Gram-negative was sensitive to Amikacin and Meropenem and highly resistance to Ampicillin and Cephalosporine. These findings suggest that prospective multicenter studies are required to assess the appropriate empirical antibiotic regimen in diabetic foot ulcers taking into consideration the etiology of ulcers. Also, the results alert us that proper management of antibiotics must be implemented to decrease the incidence of resistant in the population. In many cases, empirical therapy is necessary, especially in therapeutic centers that have no microbiology laboratories and limited resources.

\section{ACKNOWLEDGEMENT: Nil}

\section{CONFLICT OF INTEREST: Nil}

\section{REFERENCES:}

1. Sociedade Brasileira de Diabetes. Diagnóstico e classificação de DM e tratamento de DM tipo 2. Available from: http://www.diabetes.org.br

2. Wild S, Roglic G, Green A, Sicree R and King H: Global prevalence of diabetes: estimates for the year 2000 and projections for 2030. Diabetes Care 2004; 27: 1047-53.

3. Malerbi DA and Franco LJ: Multicenter study of the prevalence of diabetes mellitus and impaired glucose tolerance in the urban Brazilian population aged 30-69 yr. The Brazilian Cooperative Group on the Study of Diabetes prevalence. Diabetes Care 1992; 15: 1509-16.

4. Goldstein EJ, Citron DM and Nesbit CA: Diabetic foot infections: bacteriology and activity of 10 oral antimicrobial agents against bacteria isolated from consecutive cases. Diabetes Care 1996; 19: 638-641.

5. Tentolouris N, Jude EB, Smirnof I, Knowles EA and Boulton AJ: Methicillin-resistant Staphylococcus aureus: an increasing problem in a diabetic foot clinic. Diabet Med 1999; 16: 767-771.

6. Shanker EM, Mohan V, Premlatha G, Srinivasan RS and Usha AR: Bacterial etiology of diabetic foot infections in South India. Eur J Intern Med 2005; 16: 567-570.

7. Hartemann-Heurtier A, Robert J, Jacqueminet S, Ha Van G, Golmard JL, Jarlier V and Grimaldi A: Diabetic foot ulcer and multidrug-resistant organisms: risk factors and impact. Diabet Med 2004; 21: 710-715.

8. Shankar EM, Mohan V, Premalatha G, Srinivasan RS and Usha AR: Bacterial etiology of diabetic foot infections in south India. Eur J Intern Med 2005; 16(8): 567-70.

9. Pathare NA, Bal A, Talvalkar GV and Antani DU: Diabetic foot infections: a study of microorganisms associated with the different wagner grades. Ind J Pathol Microbiol 1998; 41(4): 437-41.

10. Anandi C, Alaguraja D, Natarajan V, Ramanathan M, Subramanium CS, Thulasiram $M$ and Sumithra S: Bacteriology of diabetic foot lesions. IJMM 2004; 22(3): 175- 178.

11. Hooton TM, Levy SB. Confronting the antibiotic resistance crisis: making appropriate therapeutic decisions in community medical practice. Infect Med2004; 21 (3): 114-22.

12. Colagan $\mathrm{R}$ and Powers JH: Appropriate antimicrobial prescribing approaches that limit antibiotic resistance. Journal of the American Academy of Family Physicians in 2001; 64(6): 999-1005.

13. Dancer SJ: The problem with cephalosporins. Journal of Anti-microbial Chemotherapy 2001; 48: 463-78.

14. Lipsky BA, Pecoraro RE, Larson SA and Ahroni JH: Outpatient management of uncomplicated lower-extremity infections in diabetic patients. Arch Intern Med 1990; 150: 790-7.

15. Ger R: Newer concepts in the surgical management of lesions of the foot in the patient with diabetes. Surg Gynecol Obstet 1984; 158: 213-5.

16. Frykberg RG and Mendeszoon ER: Charcot arthropathy: pathogenesis and management. Wounds 2000; 12(S- B): $35-42$.

17. Shankar EM, Mohan V, Premalatha G, Srinivasan RS and Usha AR: Bacterial etiology of diabetic foot infections in south India. Eur J Intern Med 2005; 16(8): 567-70.

18. Citron DM, Goldstein EJL, Merriam CV, Lipsky BA and Abrarnson MA: Bacteriology of moderate to severe diabetic wound infections. Jour Clin Mic 2007; 28192828 . 
19. Hunt JA: Foot infections in diabetes are rarely due to a single microorganism. Diabet Med 1992; 9(8): 749-52

20. Viswanathan V, Jasmine JJ, Snehalatha C and Ramachandran A: Prevalence of pathogens in diabetic foot infection in South Indian type 2 diabetic patients. J Assoc Physicians India 2002; 50: 1013-6.

21. Anandi C, Alaguraja D, Natarajan V, Ramanathan M, Subramaniam CS, Thulasiram $M$ and Sumithra S: Bacteriology of diabetic foot lesions. Indian $\mathrm{J}$ Med Microbiol 2004; 22(3): 175-8.

22. Candel Gonzalez FJ, Alramadan M, Matesanz M, Diaz A, Gonzalez-Romo F and Candel I: Infections in the diabetic foot, ulcers. Eur J Intern Med 2003; 14: 341-3.

23. Goldstein EJ, Citron DM and Nesbit CA: Diabetic foot infections: bacteriology and activity of 10 oral antimicrobial agents against bacteria isolated from consecutive cases. Diabetes Care 1996; 19: 638-641.

24. Dang CN, Prasad YD, Boulton AJ and Jude EB: Methicillin-resistant Staphylococcus aureus in the diabetic foot clinic: a worsening problem. Diabet Med 2003; 20: 159-161.

25. Dhawan GB, Sreenivas V, Kapil A, Ammini AC and Chaudhry R: A clinico-microbiological study of diabetic foot ulcers in an Indian tertiary care hospital. Diabetes Care 2006; 29: 1727-1732.

26. Shankar EM, Mohan V, Premalatha G, Srinivasan RS and Usha AR: Bacterial aetiology of diabetic foot infections in South India. Eur. J. Intern. Med. 16:567-570.

27. Gadepalli R, Dhawan B, Sreenivas V, Kapil A, Ammini AC, Chaudhry R: A clinico - microbiological study of diabetic foot ulcers in an Indian tertiary care hospital. Diabetes Care 2006; 29(8): 1727-32.

28. Citron DM, Goldstein EL, Merriam CV, Lipsky BA and Abrarnson MA: Bacteriology of moderate to severe diabetic wound infections. Jour Clin Mic 2007; 28192828 .

29. Lipsky BA, Berendt AR, Deery HG, Embil JM, Joseph WS, Karchmer AW, LeFrock JL, Lew DP, Mader JT, Norden C and Tan JS: Diagnosis and treatment of diabetic foot infections. Clin Infect Dis 2004; 39: 885-910.

30. El-Tahawy AT: Bacteriology of diabetic foot. Saudi Med J 2000; 21(4): 344-7.

31. Zeillemaker AM, Veldkamp KE, van Kraaij MG, Hoekstra JB, Hoynck van Papendrecht AA and Diepersloot RJ: Piperacillin/tazobactam therapy for diabetic foot infection. Foot Ankle Int 1998; 19(3): 169-72.

32. Citron DM, Goldstein EL, Merriam CV, Lipsky BA and Abrarnson MA: Bacteriology of moderate to severe diabetic wound infections. Jour Clin Mic 2007; 28192828.

33. Slater RA, Lazarovithch T, Bolduri, Ra Mot Y and Buchs A: Swab culture accurately identify the bacterial pathogen in diabetic foot wounds not involving bone. Diabet Med 2004; 21(7): 705-9.

34. Unachukwu $\mathrm{CN}$, Objunge $\mathrm{OK}$ and Odia OJ: The bacteriology of diabetic foot ulcer in Port Harcourt, Nigeria. Niger J med 2005: 14(2): 173-6

35. Raja NS: The microbiology of diabetic foot infections in a teaching hospital in Malaysia: a retrospective study of 194 cases. J Microbial Immunol Infect 2007; 40: 39-44.

How to cite this article:

Javad FS, Reazvanian M, Kumar S and Norouzi H: Microbiological study of diabetic foot ulcers in an Indian Tertiary Care Hospital. Int J Life Sci \& Rev 2015; 1(2): 65-70. doi: 10.13040/IJPSR.0975-8232.IJLSR.1(2).65-70.

All $\odot 2015$ are reserved by International Journal of Life Sciences and Review. This Journal licensed under a Creative Commons Attribution-NonCommercial-ShareAlike 3.0 Unported License.

This article can be downloaded to ANDROID OS based mobile. Scan QR Code using Code/Bar Scanner from your mobile. (Scanners are available on Google Playstore) 